\title{
Some validation aspects on the analytical method for assaying carcinogenic amines from textile dyes
}

DOI: $10.35530 / I T .069 .03 .1521$

ELENA PERDUM

IULIANA DUMITRESCU

ANDREI VALENTIN MEDVEDOVICI

FLORENTIN TACHE

EMILIA VISILEANU

\author{
CORNELIA-ELENA MITRAN \\ OVIDIU-GEORGE IORDACHE \\ ION RAZVAN RADULESCU
}

\author{
REZUMAT - ABSTRACT
}

\section{Aspecte privind validarea metodei analitice de determinare a aminelor cancerigene derivate din coloranți specifici industriei textile}

Controlul siguranței chimice, precum și proprietățile ecologice au devenit o prioritate pentru industria textilă cu scopul de a evita efectele negative ale substanțelor chimice asupra oamenilor și asupra mediului înconjurător. Interesul crescut pentru toxicologia produselor textile este determinat de prezența compușilor periculoși în haine generați în urma proceselor de vopsire și de finisare. Pentru a proteja sănătatea umană, regulamentele europene, precum Oeko Tex Standard 100 și REACH, limitează prezența substanțelor chimice periculoase, cum ar fi aminele aromatice generate prin scindarea reductivă a coloranților azoici, la cel mult 30 mg/kg de material textil. Scopul principal al acestei lucrări de cercetare a fost elaborarea și validarea metodei cromatografice HPLC/MWD pentru identificarea și cuantificarea precisă și sigură a aminelor aromatice cancerigene derivate din coloranți azo specifici industriei textile. Determinarea simultană a 24 de amine aromatice reglementate a fost efectuată prin două metode cromatografice conform SR EN ISO 14362-1: 2017 pentru a evita interferențele matricei și erorile în identificarea compușilor din cauza prezenței izomerilor structurali. Analizele preliminare pentru a stabili lungimea de undă corespunzătoare absorbției maxime a fiecărei soluții standard de amine aromatice s-au efectuat simultan la patru lungimi de undă, 240, 280, 305 și $380 \mathrm{~nm}$. Cu scopul de a demonstra siguranța, fiabilitatea și precizia datelor analizate, s-au validat atât metoda cromatografiei de lichide, cât și cea a cromatografiei de gaze. Au fost evaluați parametri ca: selectivitatea, precizia, limita de detecție și limita de cuantificare a celor două metode analitice. Certitudinea determinărilor a fost dovedită și de rezultatele testelor interlaboratoare efectuate de Institutul de Studii Interlaboratoare din Olanda asupra coloranților azoici din textile.

Cuvinte cheie: testarea competențelor, amine cancerigene, textile vopsite, textile ecologice, HPLC, GC-MS, validare

\section{Some validation aspects on the analytical method for assaying carcinogenic amines from textile dyes}

Chemicals safety control and ecological properties have become a priority for the textile industry in order to avoid the negative effects on humans and environment. The increasing interest for toxicology of textiles is determined by the presence of dangerous compounds in clothes generated from dyeing and finishing processes. In order to protect human health, European Regulations as Oeko Tex Standard 100 and REACH Regulation limit the presence of dangerous chemicals, such as aromatic amines, generated by reductive cleavage of azo dyes, by no more than $30 \mathrm{mg} / \mathrm{kg}$ of textile material. The main goal of this research work was to develop and validate a HPLC/MWD method for precise and reliable identification and quantification of carcinogenic aromatic amines derived from banned azo dye specific to the textile industry. The simultaneous determination of 24 regulated aromatic amines has been conducted by two chromatographic methods according to SR EN ISO 14362-1:2017 in order to avoid matrix interferences and compounds misidentification due to the presence of structural isomers. Preliminary analyses to establish the maximum absorption wavelength of each standard solution of aromatic amine were performed simultaneously at four wavelengths, 240, 280, 305 and $380 \mathrm{~nm}$. With the scope of demonstrating the consistency, reliability and accuracy of the analysed data, both liquid and gas chromatographic method were validated. Parameters as selectivity, precision, limit of detection and limit of quantification of the analytical methods were evaluated. The certainty of the determinations was also proved by the results of proficiency testing conducted by IIS Netherlands on azo dyes in textiles.

Keywords: proficiency testing, carcinogenic amines, textile dyes, textile ecology, HPLC, GC-MS, validation

\section{INTRODUCTION}

Azo colourants are used to colour textile fibres, leather, plastics, papers, hair, mineral oils, waxes, foodstuffs and cosmetics [1-2]. 'Azo dye' is the collective term used to describe a group of synthetic that rose to prominence in the 1880s and are now comprise $70 \%$ of all organic commercial dyes [1]. The word 'Azo' signifies the presence of a chemical azo group $(-\mathrm{N}=\mathrm{N}-)$ in the dye. Today, they are produced for the most part in China and India, followed by Korea, China and Argentina [1]. Azo dyes are popularly used, because they dye cloth at $60^{\circ} \mathrm{C}$, while Azo-free dyes require a temperature of $100^{\circ} \mathrm{C}$. Also, Azo dyes offer an extensive range of colours, better colour fastness and four times the intensity of the closest alternatives, making them invaluable to the textile industry. 
In specific conditions, azo dyes produce by in vivo reductive cleavage of the azo groups primary aromatic amines (PAAs), that are considered by the international authorities to be toxic, and have mutagenic and carcinogenic effect. These specific reductive conditions are met in the digestive tracts and some organs of animals, including humans [3]. The main responsible for their toxicity is represented by the amino group bound to the aromatic system. 24 aromatic amines have been confirmed as or implicated to be, carcinogens in humans, and as many as 5\% of Azo dyes can cleave to form these dangerous compounds [2]. They can be present in dyed product and in the environment due to incomplete synthesis or degradation of azo dyes.

There are three main routes of exposure to azo dyes: a) ingestion, mainly by babies and children, b) dermal absorption, the largest concern both for people wearing dyed clothing and for the staff from factories producing dyes and c) dye inhalation worrying for workers from factories but also for handling freshly dyed materials with azo dyes [1].

In one German dye plant, $100 \%$ of workers (15 people) involved in distilling 2-naphthylamine developed bladder cancer [4]. Aromatic amines are also present in tobacco smoke, which may explain why smoking seems to elevate the risk of bladder cancer. EU restricted aromatic amines have also been linked to splenic sarcomas and hepatocarcinomas [6].

Many strict government regulations worldwide limit the usage of azo dyes in textile and leather products. 22 aromatic amines are classified by the EU Commission as proven or suspected human carcinogens, and their concentration in textile materials is limited at $30 \mathrm{mg} / \mathrm{kg}$ [1]. Oeko-Tex Label, designed to protect the consumers is a voluntary label adopted by an increasing number of textile manufacturers, and regulates 24 aromatic amines, of which 22 overlap with the European legislation. The maximum amount of carcinogenic aromatic amines specified in Oeko Tex is $20 \mathrm{mg} / \mathrm{kg}$ [2].

The increasing need for less harmful chemicals used in textile industry, that have minimum of no harmful effects on human health justify the necessity for fast and accurate methods to test and quantify aromatic amines derived from azo dyes extracted from textile materials [2].

\section{EXPERIMENTAL}

\section{Reagents and standards}

Acetonitrile and methanol gradient grade from Merck KGaA (Germany), water for chromatography (resistivity min. $18.2 \mathrm{M} \Omega \times \mathrm{cm}$, TOC max. $50 \mathrm{ppb}$ ).

Analytical standards of 24 aromatic amines from Sigma-Aldrich and Dr. Ehrenstorfer GmbH (Germany). Instrumentation

HPLC separation was performed on Agilent 1100 LC System using an Agilent Zorbax Eclipse XDB C18 column and MWD detector. GC separation was performed on Agilent 6890 GC System coupled with

\begin{tabular}{|c|c|c|}
\hline \multicolumn{3}{|c|}{ Agilent $6890 \mathrm{GC} / 5973 \mathrm{~N}$ MS Operating Conditions } \\
\hline Capillary Column & \multicolumn{2}{|c|}{$\begin{array}{l}\text { DB-35MS (J\&W), } 35 \mathrm{~m} \times \\
0.25 \mathrm{~mm} \times 0.25 \mu \mathrm{m} ;\end{array}$} \\
\hline Injector System & \multicolumn{2}{|l|}{ splitless } \\
\hline Injector Temp. & \multicolumn{2}{|l|}{$260^{\circ} \mathrm{C}$} \\
\hline Carrier gas & \multicolumn{2}{|l|}{ helium } \\
\hline Flow (mL/min) & \multicolumn{2}{|l|}{$1 \mathrm{~mL} / \mathrm{min}$} \\
\hline Temp. programme & \multicolumn{2}{|c|}{$\begin{array}{l}100^{\circ} \mathrm{C}(2 \mathrm{~min}) \\
100^{\circ} \mathrm{C}-310^{\circ} \mathrm{C}\left(15^{\circ} \mathrm{C} / \mathrm{min}\right), \\
310^{\circ} \mathrm{C}(2 \mathrm{~min}) \\
\end{array}$} \\
\hline Injection Volume & \multicolumn{2}{|c|}{$1.0 \mu \mathrm{l}$} \\
\hline Detection & \multicolumn{2}{|c|}{ MS / Full Scan } \\
\hline Acquisition Parameters & \multicolumn{2}{|c|}{ El Positive Ion Mode, $70 \mathrm{eV}$} \\
\hline \multicolumn{3}{|c|}{ Agilent 1100 HPLC/MWD Operating Conditions } \\
\hline Analytical Column & \multicolumn{2}{|c|}{$\begin{array}{l}\text { Zorbax Eclipse XDB C18 } 150 \mathrm{~mm} \\
\text { x 4,6 mm x 3.5 } \mathrm{mm}\end{array}$} \\
\hline Column Temp. & \multicolumn{2}{|c|}{$32^{\circ} \mathrm{C}$} \\
\hline Injection Volume & \multicolumn{2}{|l|}{$5.0 \mu \mathrm{l}$} \\
\hline \multirow[t]{2}{*}{ Mobile Phase } & \multicolumn{2}{|c|}{ Eluent 1: methanol } \\
\hline & \multicolumn{2}{|c|}{$\begin{array}{l}\text { Eluent } 2: 0.68 \mathrm{~g} \text { potassium } \\
\text { dihydrogen phosphate in } 1000 \mathrm{~mL} \\
\text { water, } 150 \mathrm{~mL} \text { methanol }\end{array}$} \\
\hline Run time & \multicolumn{2}{|c|}{$35 \min$} \\
\hline Flow rate & \multicolumn{2}{|c|}{$0,6-2,0 \mathrm{~mL} / \mathrm{min}$ (gradient) } \\
\hline Quantification & \multicolumn{2}{|c|}{$\begin{array}{l}\text { at } 240 \mathrm{~nm}, 280 \mathrm{~nm}, 305 \mathrm{~nm} \text { and } \\
380 \mathrm{~nm}\end{array}$} \\
\hline \multirow[t]{10}{*}{ Gradient profile } & Time (minutes) & $\begin{array}{l}\text { Gradient (\% } \\
\text { Eluent 1) }\end{array}$ \\
\hline & 0.00 & 10.0 \\
\hline & 22.50 & 55.0 \\
\hline & 27.50 & 100.0 \\
\hline & 28.50 & 100.0 \\
\hline & 28.51 & 100.0 \\
\hline & 29.00 & 100.0 \\
\hline & 29.01 & 10.0 \\
\hline & 31.0 & 10.0 \\
\hline & 35.00 & 10.0 \\
\hline
\end{tabular}

Agilent $5973 \mathrm{~N}$ transmission quadrupole mass spectrometer (table 1).

Sample preparation

Stock solutions of each amine (according to - SR EN ISO 14362-1:2017 [2]) with the concentration of 300 $\mu \mathrm{g} / \mathrm{mL}$ in ACN were prepared. From these stock solutions, 8 solutions for calibration curve were prepared, with the following concentration: $3,4.5,6,12,24,28$, $30,36 \mu \mathrm{g} / \mathrm{mL}$.

\section{Selection of maximum absorption wavelength for each of 22 aromatic amines}

Each standard solution of the target amines in concentration of $50 \mu \mathrm{g} / \mathrm{mL}$ was analysed using spectrophotometric detection simultaneously at four wavelengths, 240, 280, 305 and $380 \mathrm{~nm}$. Thus, a classification of the 24 amines depending on the 


\begin{tabular}{|c|c|c|c|}
\hline $\mathbf{2 4 0} \mathbf{n m}$ & $\mathbf{2 8 0} \mathbf{n m}$ & $\mathbf{3 0 5} \mathbf{n m}$ & $\mathbf{3 8 0} \mathbf{n m}$ \\
\hline Amines $3,4,6,7,8,9,13,14,15,16,17,18,19,20,21^{*}$ & Amines 2, 12, 1, 10 & Amines 11 & Amines 5, 22 \\
\hline
\end{tabular}

* according to aromatic amines numbering from table 1 - ISO/FDIS 14362-1:2016(E) [8]

specific wavelength at which absorption is maximal was obtained (table 2).

The overlaid chromatograms of amines $3,2,11$, and 22 , solutions with concentration of $50 \mathrm{mg} / \mathrm{L}$ are shown

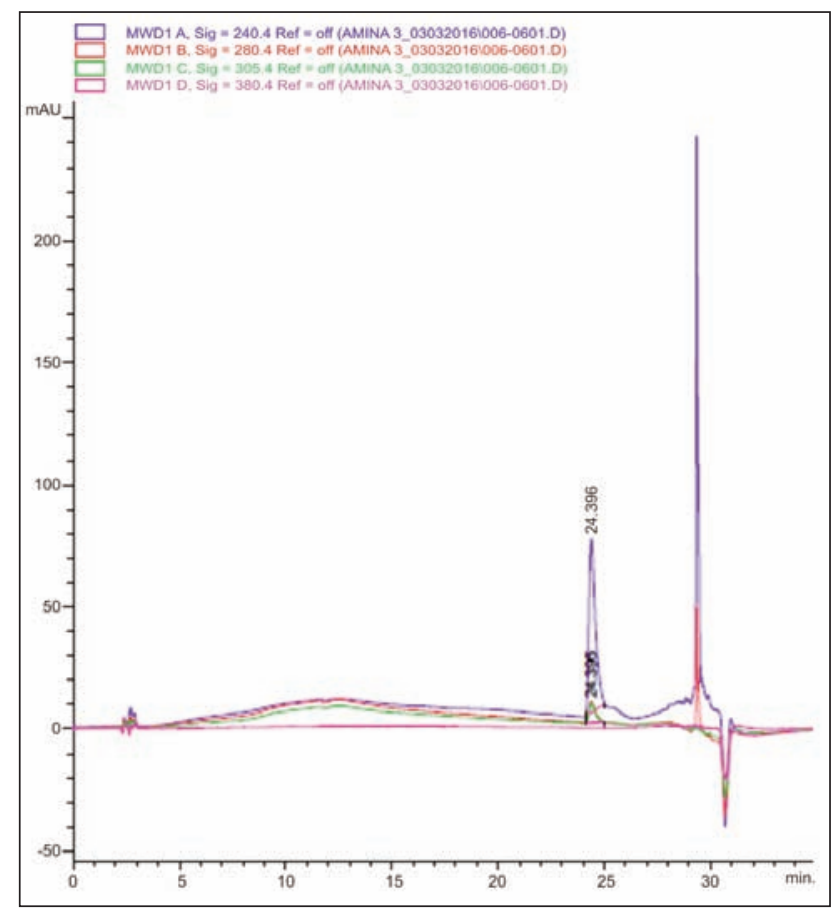

Fig. 1. Overlaid chromatograms of 4-chloro-o-toluidine, $50 \mathrm{mg} / \mathrm{L}$, maximum absorption wavelength at $240 \mathrm{~nm}$

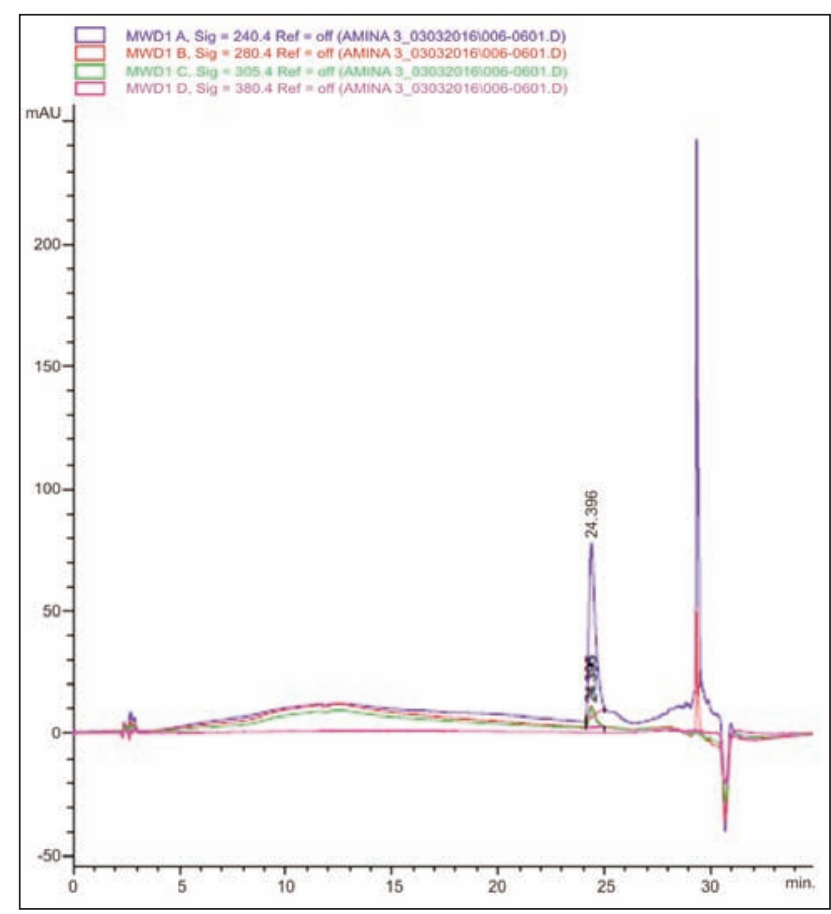

Fig. 3. Overlaid chromatograms of o-dianisidine, $50 \mathrm{mg} / \mathrm{L}$, maximum absorption wavelength at $305 \mathrm{~nm}$ in figures 1-4. Detection has been performed at 240, 280,305 and $380 \mathrm{~nm}$ and the overlaid chromatograms indicate the detection wavelength for each amine.

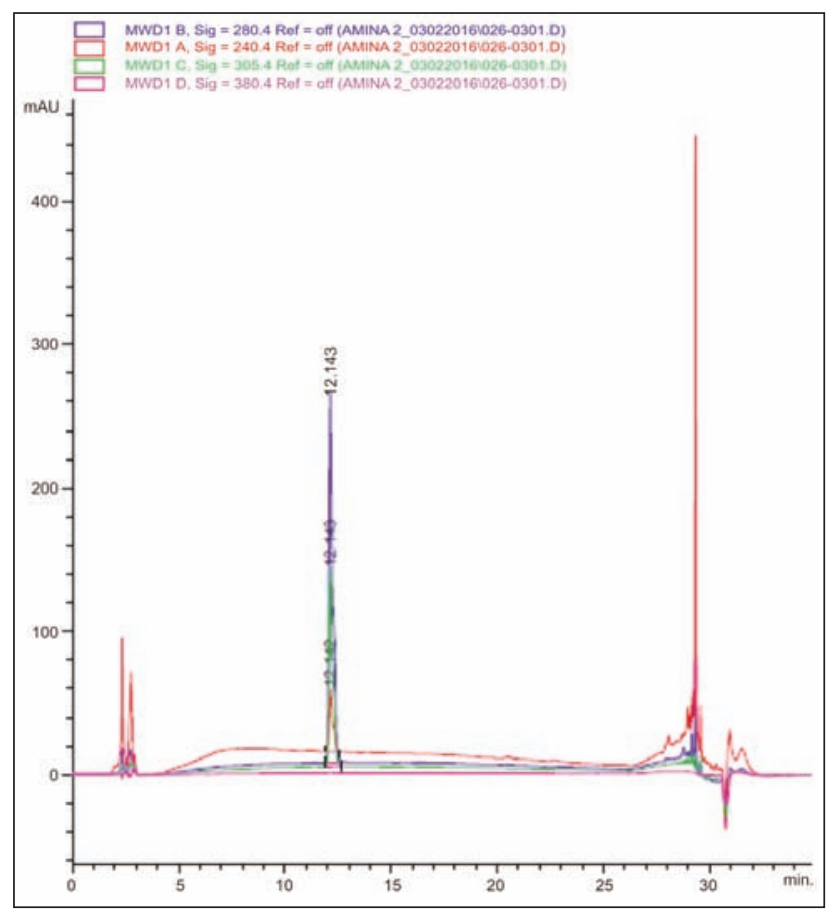

Fig. 2. Overlaid chromatograms of benzidine, $50 \mathrm{mg} / \mathrm{L}$, maximum absorption wavelength at $280 \mathrm{~nm}$

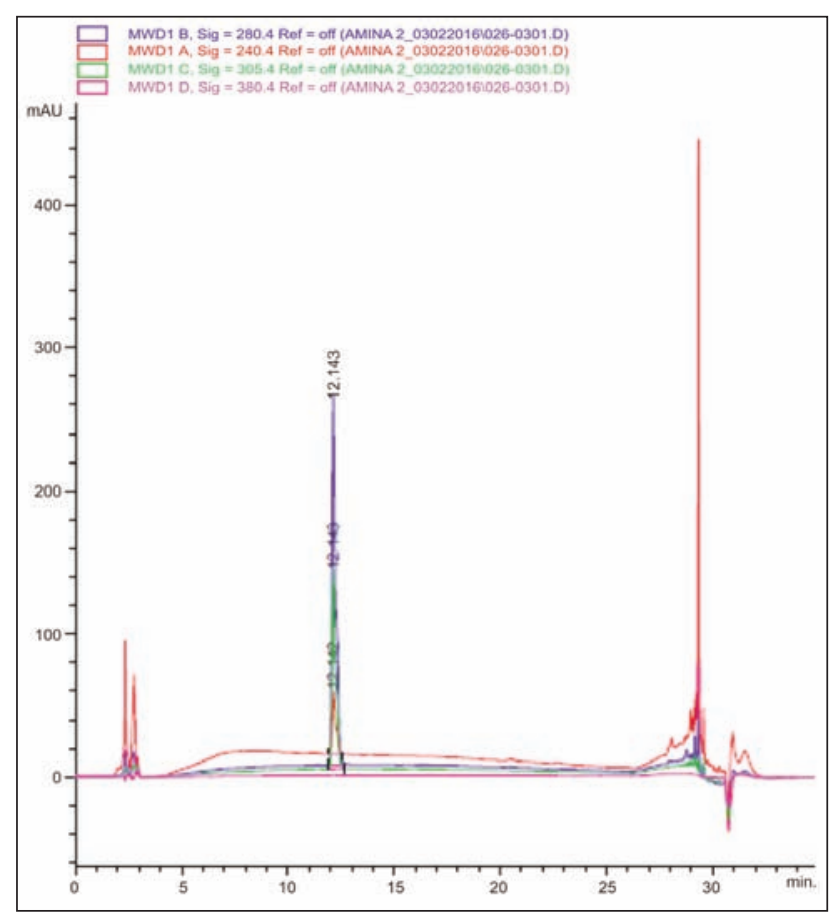

Fig. Overlaid chromatograms of 4-aminoazobenzene, $50 \mathrm{mg} / \mathrm{L}$, maximum absorption wavelength at $380 \mathrm{~nm}$ 
Performance characteristics of the analytical method

\section{Selectivity}

Selectivity is the ability of the analytical method to measure and differentiate analytes in the presence of components that are expected to be present in the sample. In the case of an HPLC method it must be demonstrated that the analyte of interest was very well separated from the other compounds in the sample and that the peak of interest did not overlap with other interfering peaks.

In order to demonstrate the method selectivity, apparent resolution and relative standard deviation (RSD $\%$ ) of retention time between each two analytes with consecutive elution have been determined (table 3). 6 chromatographic separation of mixture of 24 amines by HPLC-MWD and GC-MS techniques have been performed. For calculation of relative standard deviation, average values of retention times were used.

As can be seen in table 3 , the chromatographic resolutions between each 2 consecutive compounds exceed in all cases the value of 1.5 and in many cases have increased values (amine 12: $R_{s}=47.128$ ), indicating very good separation capacity of the amine mixture on the Zorbax Eclipse XDB C18 column.

The relative standard percentage deviation calculated for average retention time is in all cases less or very close to the value of 1 , showing a good selectivity of the separation method of aromatic amines [11]. As it can be observed in figures 5-8 and table 3, all amines were evaluated at the wavelength corresponding to their maximum absorption; compounds are well separated at their baseline, with no fronting, tailing or overlapping peaks.

\section{Precision}

Measurement precision express the closeness of the results obtained from a series of multiple measurements

\begin{tabular}{|c|c|c|c|c|}
\hline \multirow{2}{*}{$\begin{array}{l}\text { Wavelength } \\
\text { correspond- } \\
\text { ing to } \\
\text { maximum } \\
\text { absorption }\end{array}$} & \multirow{2}{*}{ Amine } & \multicolumn{3}{|c|}{ HPLC Results } \\
\hline & & $\begin{array}{c}t_{R} \\
\text { (average) }\end{array}$ & $\begin{array}{c}\mathrm{R}_{\mathrm{S}} \\
\text { (average) }\end{array}$ & RSD\% \\
\hline \multirow[t]{16}{*}{$240 \mathrm{~nm}$} & Amine 8 & 3.955 & 3.19 & 0.59 \\
\hline & Amine 19 & 4.890 & 29.93 & 0.50 \\
\hline & Amine 16 & 12.284 & 5.58 & 0.86 \\
\hline & Amine 21 & 13.624 & 4.46 & 0.77 \\
\hline & Amine 18 & 14.901 & 9.90 & 0.73 \\
\hline & Amine 9 & 17.617 & 3.65 & 0.46 \\
\hline & Amine 7 & 18.618 & 1.06 & 1.43 \\
\hline & Amine 6 & 18.922 & 3.57 & 0.85 \\
\hline & Amine 14 & 20.090 & 1.73 & 0.60 \\
\hline & Amine 23 & 20.837 & 1.36 & 0.54 \\
\hline & Amine 24 & 21.209 & 5.43 & 0.61 \\
\hline & Amine 4 & 22.553 & 6.02 & 0.97 \\
\hline & Amine 3 & 24.207 & 4.11 & 0.96 \\
\hline & Amine 13 & 25.272 & 1.42 & 0.82 \\
\hline & Amine 20 & 25.603 & 16.81 & 0.69 \\
\hline & Amine 15 & 28.670 & 16.81 & 0.07 \\
\hline \multirow[t]{4}{*}{$280 \mathrm{~nm}$} & Amine 2 & 11.601 & 37.75 & 0.85 \\
\hline & Amine 12 & 19.680 & 47.12 & 0.66 \\
\hline & Amine 1 & 27.727 & 5.43 & 0.51 \\
\hline & Amine 10 & 28.306 & 5.43 & 0.23 \\
\hline $305 \mathrm{~nm}$ & Amine 11 & 19.362 & 1.53 & 0.64 \\
\hline \multirow[t]{2}{*}{$380 \mathrm{~nm}$} & Amine 5 & 28.605 & 12.25 & 0.13 \\
\hline & Amine 22 & 29.173 & 12.25 & 0.09 \\
\hline
\end{tabular}

of aliquots from the same homogeneous sample in specific conditions.

Reproducibility, component of precision, was addressed in the present study by participating in the

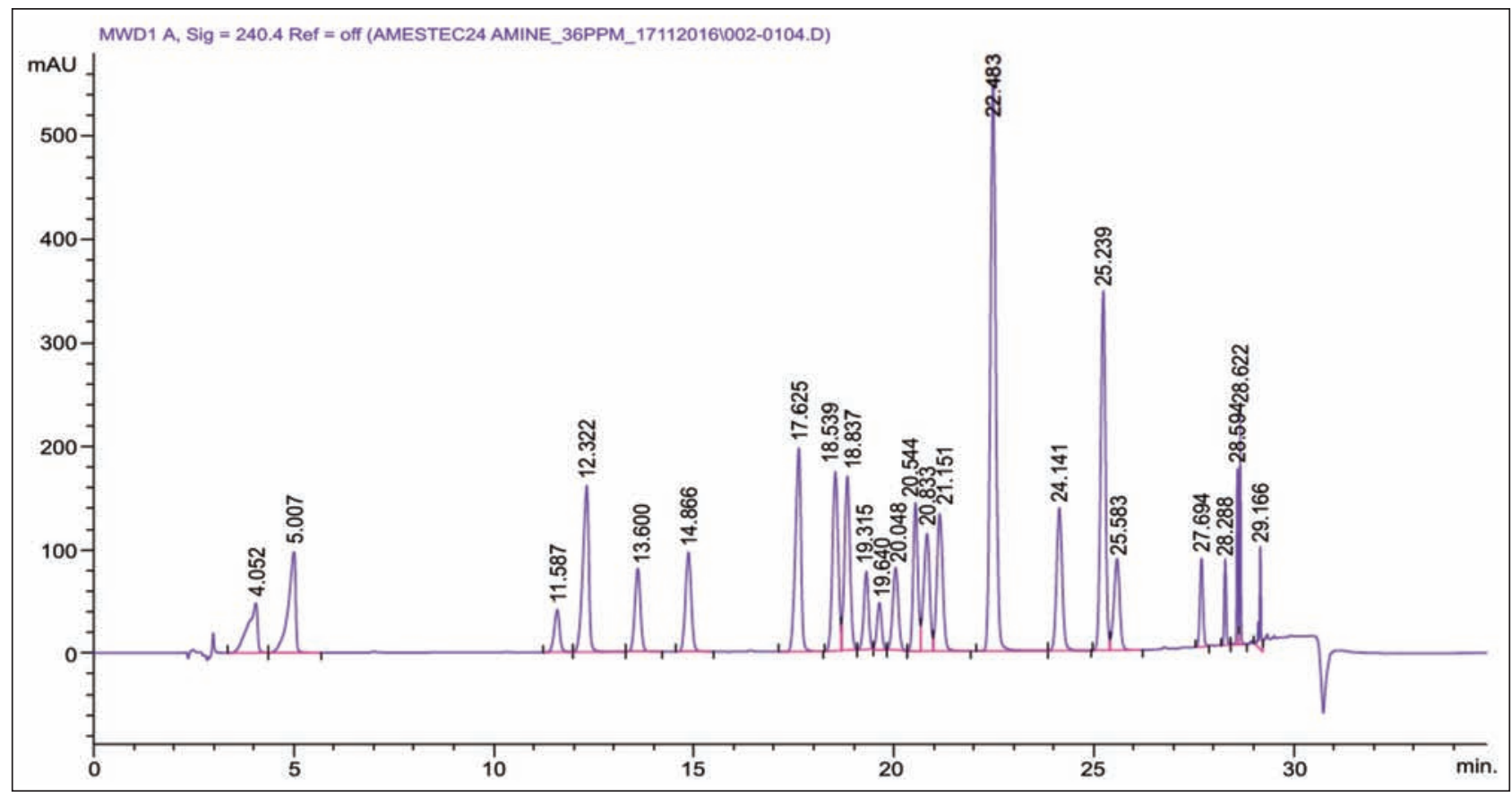

Fig. 5. Chromatogram of 24 amines mixture, concentration $36 \mathrm{ppm}$, detection at $240 \mathrm{~nm}$ 


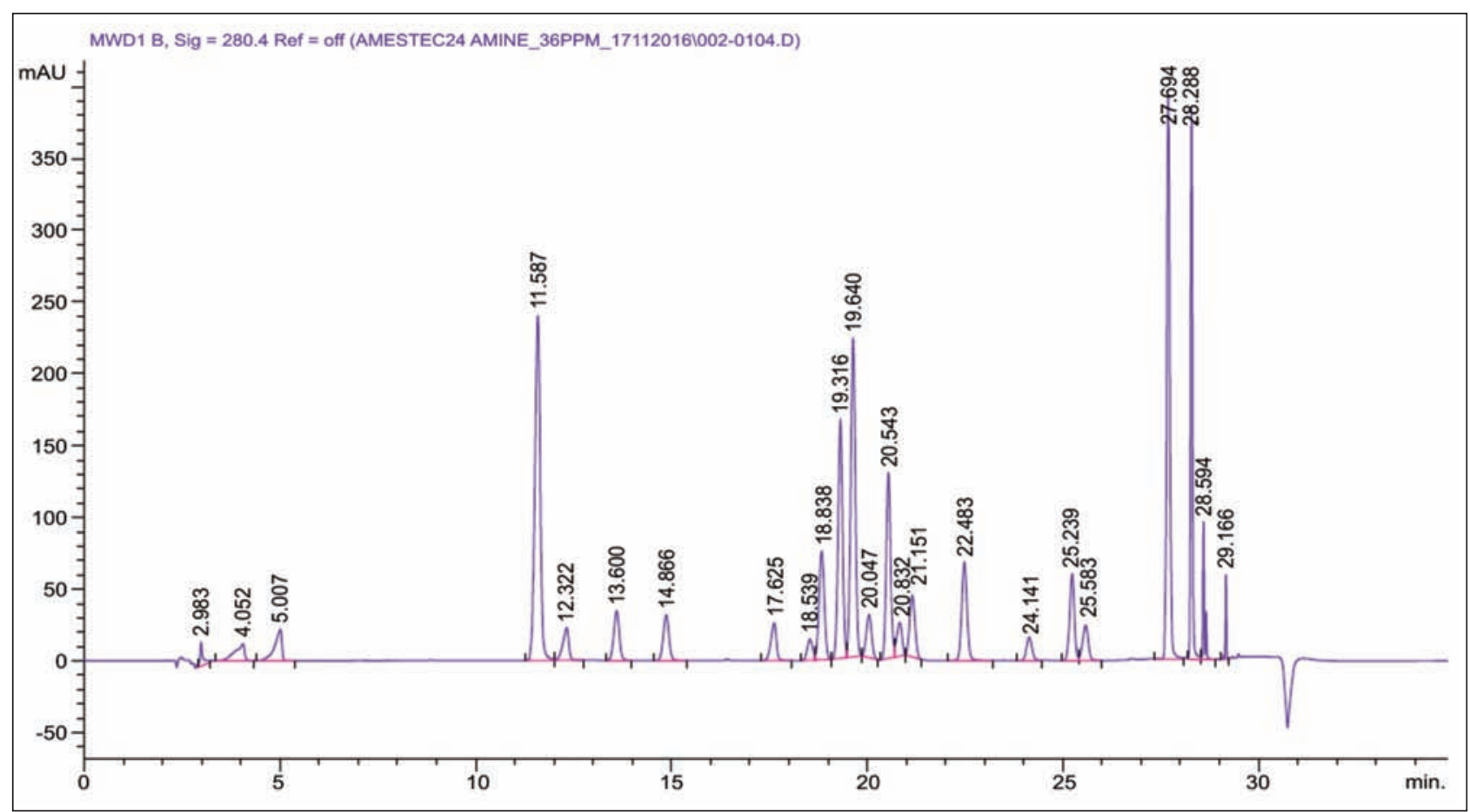

Fig. 6. Chromatogram of 24 amines mixture, concentration $36 \mathrm{ppm}$, detection at $280 \mathrm{~nm}$

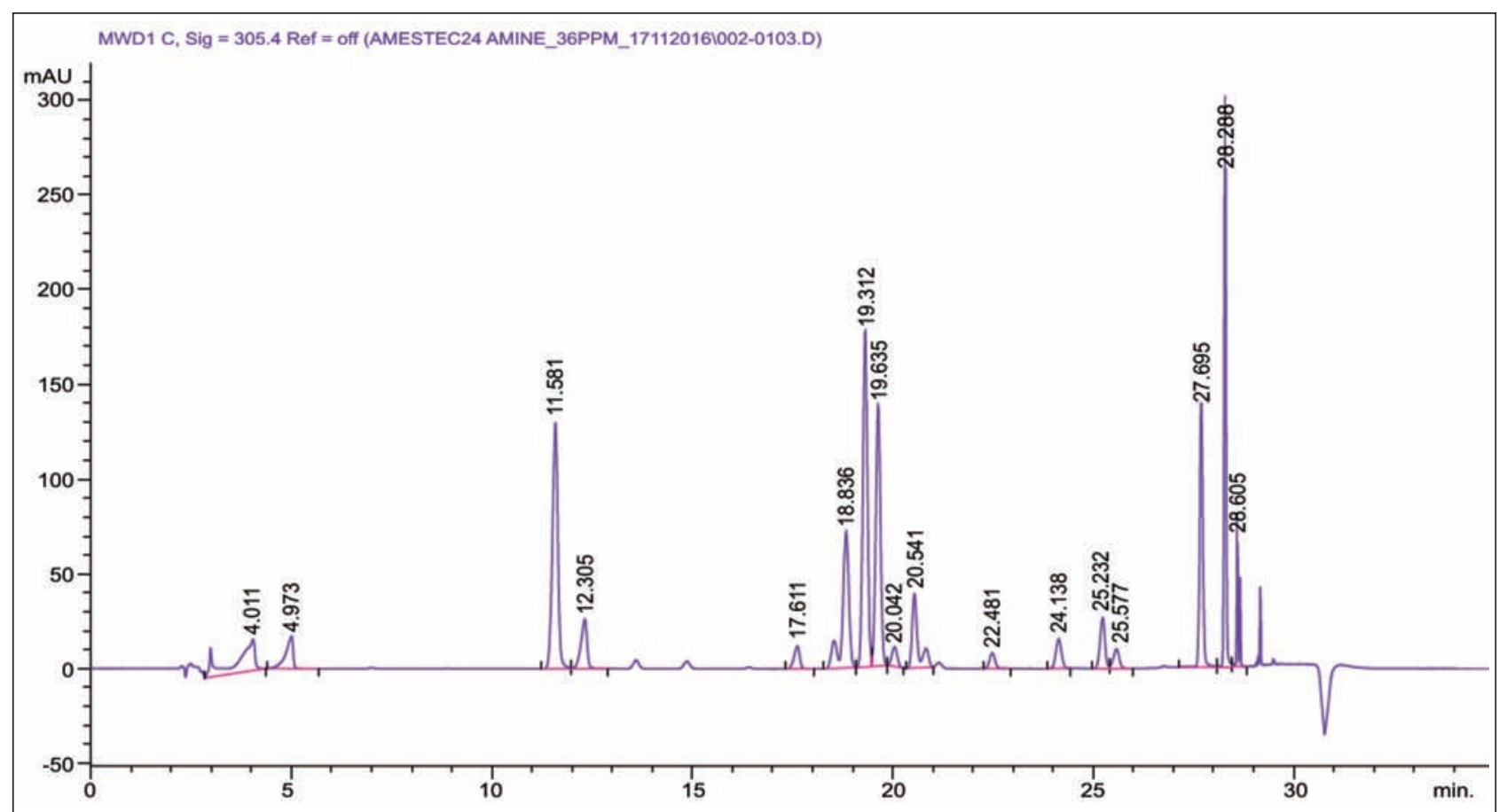

Fig. 7. Chromatogram of 24 amines mixture, concentration $36 \mathrm{ppm}$, detection at $305 \mathrm{~nm}$

interlaboratory comparison with the Institute for Interlaboratory Studies in Spijkenisse, the Netherlands. In this study, 170 laboratories from 34 different countries participated. Two different samples of fabric were made available - a sample of cotton and a sample of polyamide, each dyed with azo dyes. In the cotton sample, 3,3'-dimethoxybenzidine aromatic amine was identified by the laboratory that organized the study, and in the polyamide sample the aromatic amines 3,3'-dimethylbenzidine and 2,4-xylidine were found.
The $z$ score is calculated to evaluate the performance of the participating laboratories. For this determination, the calculated $z$ score was our laboratory was -1.92 , which is satisfactory according to literature [3] (figure 9).

For this determination, the calculated $z$ score was -0.01 (good), indicating a good reproducibility of the method for determining the aromatics of textile materials (figure 10). 


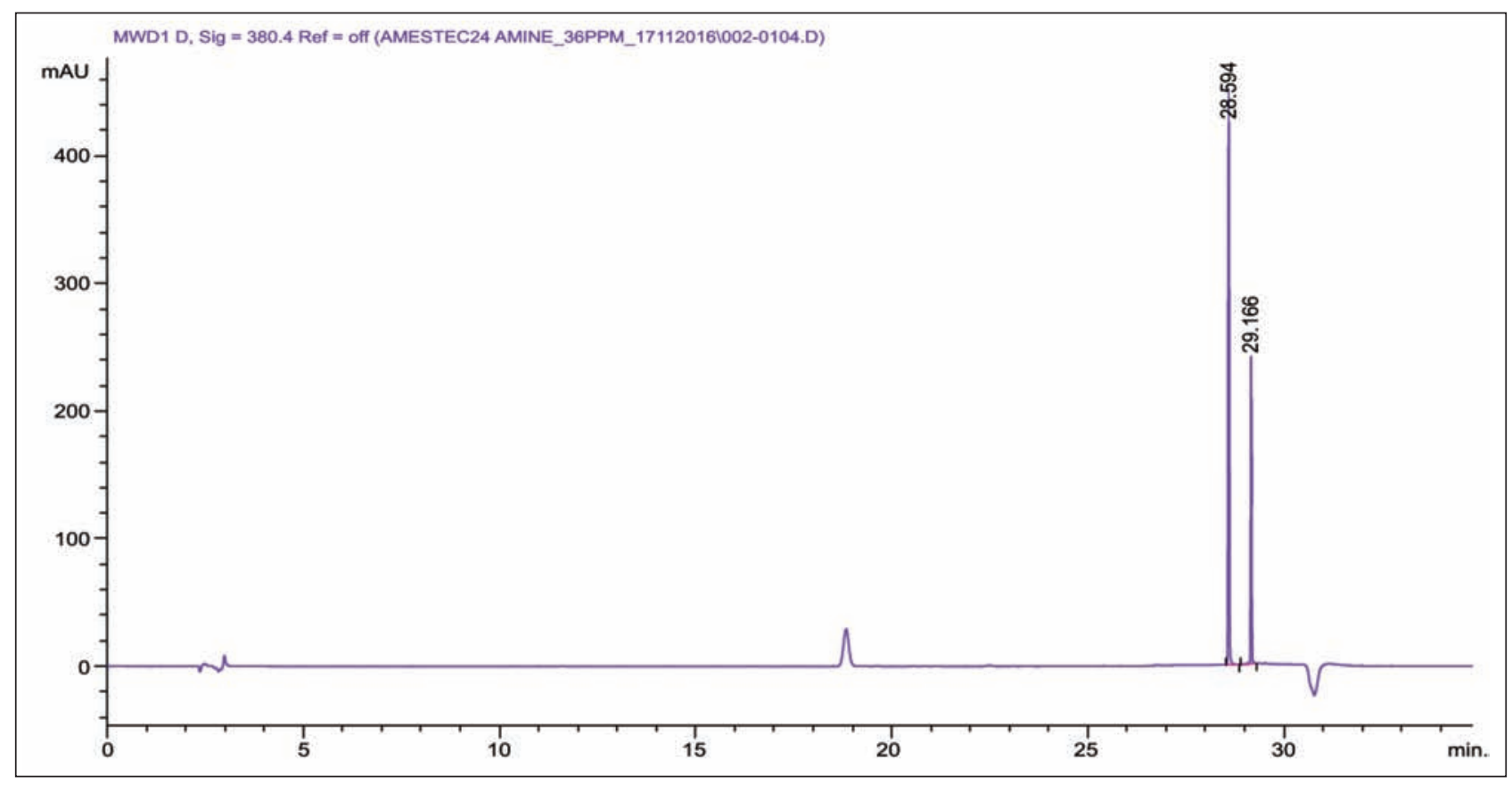

Fig. 8. Chromatogram of 24 amines mixture, concentration $36 \mathrm{ppm}$, detection at $380 \mathrm{~nm}$

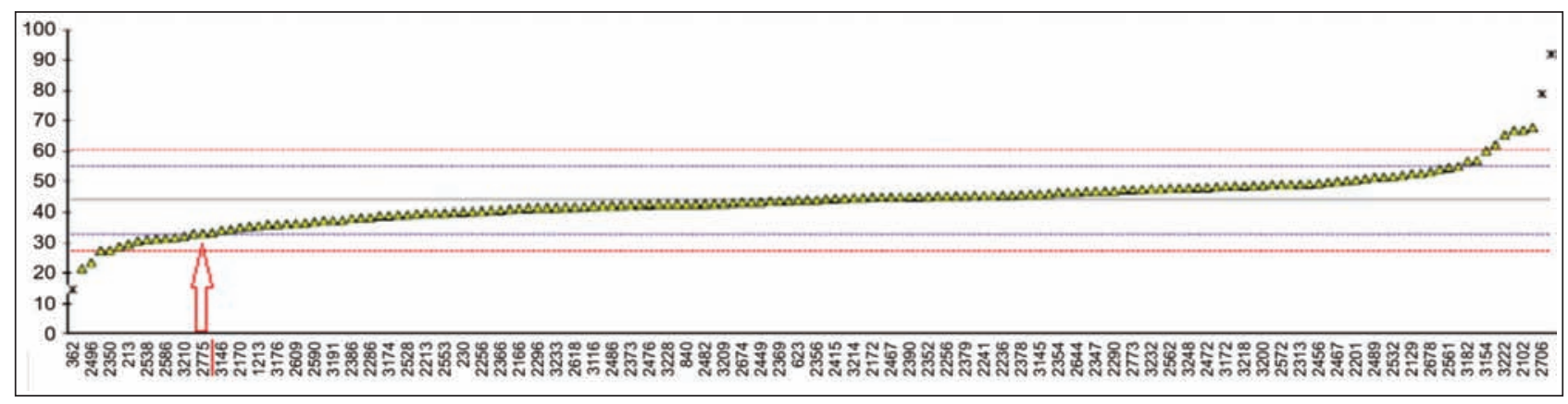

Fig. 9. Concentrations determined by the participating laboratories for 3,3'-dimethoxybenzidine in the cotton sample and positioning of our laboratory (code 2775) in the graph

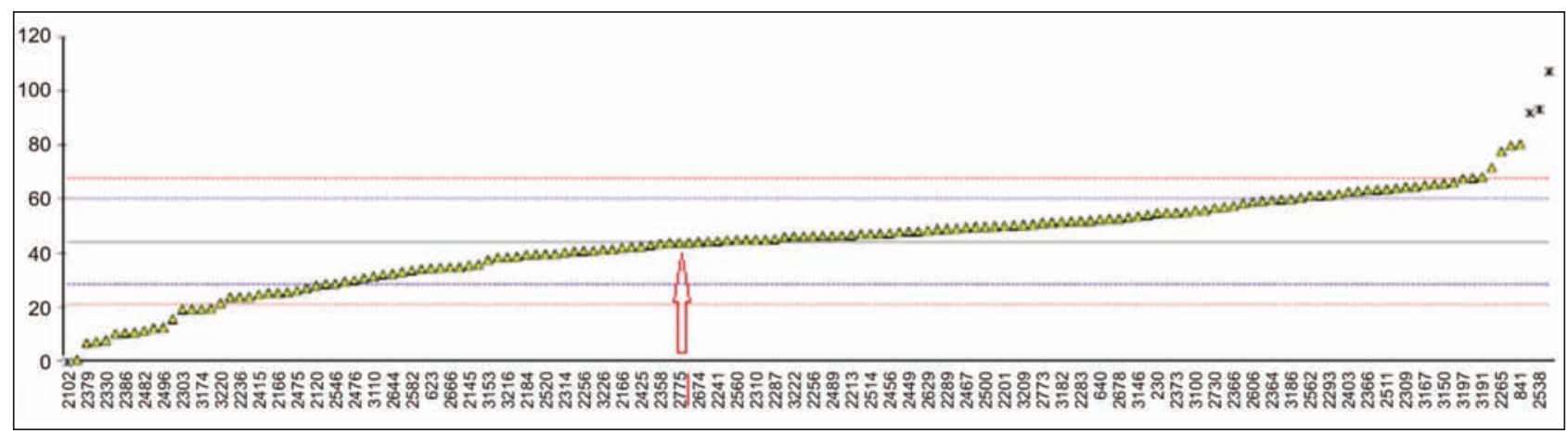

Fig. 10. Concentrations determined by the participating laboratories for 3,3'-dimethylbenzidine in the poliamide sample and positioning of our laboratory (code 2775 ) in the graph

The limit of detection (LOD) and limit of quantification (LOQ)

The limit of detection is the lowest value of the analyte concentration providing a signal (a chromatographic peak) at least equal to $3 \sigma$ ( $\sigma-$ the standard deviation of the noise in the chromatogram baseline) [3].

The limit of quantification is the value of the concentration determined in the sample under well-specified measurement conditions with acceptable repeatability and accuracy.

To determine the detection limit, an injection of the 24 amine mixture was performed by both gas and liquid chromatography, of 6 independent blank samples fortified at the lowest acceptable concentration (3 ppm), measured once each. The values obtained for the detection limits of the 24 individual amines for the two 
Table 4

\begin{tabular}{|l|c|c|c|c|c|c|}
\hline \multicolumn{1}{|c|}{ Amine } & $\begin{array}{c}\text { Average conc. } \\
\text { HPLC [ppm] }\end{array}$ & $\mathbf{s}_{\text {HPLC }}$ & LOD HPLC & $\begin{array}{c}\text { Average conc. } \\
\text { GC [ppm] }\end{array}$ & $\mathbf{s}_{\text {GC }}$ & LOD $_{\text {GC }}$ \\
\hline Amine 8 & 2.9533 & 0.0404 & $\mathbf{0 . 1 2}$ & 3.7920 & 0.1809 & $\mathbf{0 . 5 4}$ \\
\hline Amine 19 & 2.1981 & 0.0316 & $\mathbf{0 . 0 9}$ & 4.0280 & 0.1859 & $\mathbf{0 . 5 5}$ \\
\hline Amine 16 & 2.9898 & 0.0298 & $\mathbf{0 . 0 8}$ & 4.0480 & 0.1571 & $\mathbf{0 . 4 7}$ \\
\hline Amine 21 & 3.0051 & 0.0137 & $\mathbf{0 . 0 4}$ & 3.3360 & 0.2140 & $\mathbf{0 . 6 4}$ \\
\hline Amine 18 & 3.0085 & 0.0143 & $\mathbf{0 . 0 4}$ & 3.4840 & 0.1534 & $\mathbf{0 . 4 6}$ \\
\hline Amine 9 & 2.9956 & 0.0281 & $\mathbf{0 . 0 8}$ & 3.9360 & 0.2459 & $\mathbf{0 . 7 3}$ \\
\hline Amine 7 & 2.9743 & 0.0176 & $\mathbf{0 . 0 5}$ & 3.5020 & 0.1480 & $\mathbf{0 . 4 4}$ \\
\hline Amine 6 & 2.9752 & 0.0178 & $\mathbf{0 . 0 5}$ & 3.8700 & 0.1339 & $\mathbf{0 . 4 0}$ \\
\hline Amine 14 & 2.9676 & 0.0169 & $\mathbf{0 . 0 5}$ & 3.4780 & 0.1770 & $\mathbf{0 . 5 3}$ \\
\hline Amine 17 & 2.9412 & 0.0239 & $\mathbf{0 . 0 7}$ & 4.1000 & 0.0780 & $\mathbf{0 . 2 3}$ \\
\hline Amine 23 & 3.0019 & 0.0188 & $\mathbf{0 . 0 5}$ & 4.4200 & 0.6325 & $\mathbf{1 . 8 9}$ \\
\hline Amine 24 & 2.9923 & 0.0198 & $\mathbf{0 . 0 5}$ & 4.3600 & 0.3145 & $\mathbf{0 . 9 4}$ \\
\hline Amine 3 & 3.0118 & 0.0364 & $\mathbf{0 . 1 0}$ & 3.4000 & 0.1476 & $\mathbf{0 . 4 4}$ \\
\hline Amine 13 & 2.9890 & 0.0191 & $\mathbf{0 . 0 5}$ & 4.3820 & 0.0538 & $\mathbf{0 . 1 6}$ \\
\hline Amine 20 & 3.0447 & 0.0217 & $\mathbf{0 . 0 6}$ & 3.7820 & 0.1541 & $\mathbf{0 . 4 6}$ \\
\hline Amine 15 & 2.9335 & 0.0150 & $\mathbf{0 . 0 4}$ & 4.3480 & 0.0567 & $\mathbf{0 . 1 7}$ \\
\hline Amine 2 & 2.9857 & 0.0212 & $\mathbf{0 . 0 6}$ & 3.9800 & 0.0738 & $\mathbf{0 . 2 2}$ \\
\hline Amine 12 & 2.9313 & 0.0479 & $\mathbf{0 . 1 4}$ & 4.2060 & 0.0550 & $\mathbf{0 . 1 6}$ \\
\hline Amine 1 & 2.9785 & 0.0265 & $\mathbf{0 . 0 7}$ & 4.2440 & 0.1183 & $\mathbf{0 . 3 5}$ \\
\hline Amine 10 & 2.9795 & 0.0202 & $\mathbf{0 . 0 6}$ & 4.2420 & 0.0412 & $\mathbf{0 . 1 2}$ \\
\hline Amine 11 & 2.9900 & 0.0226 & $\mathbf{0 . 0 6}$ & 3.8860 & 0.0898 & $\mathbf{0 . 2 6}$ \\
\hline Amine 5 & 2.9773 & 0.0169 & $\mathbf{0 . 0 5}$ & 3.9180 & 0.0979 & $\mathbf{0 . 2 9}$ \\
\hline Amine 22 & 3.0718 & 0.0213 & $\mathbf{0 . 0 6}$ & 3.9360 & 0.1179 & $\mathbf{0 . 3 5}$ \\
\hline
\end{tabular}

Table 5

\begin{tabular}{|l|c|c|c|c|c|c|}
\hline \multicolumn{1}{|c|}{ Amina } & $\begin{array}{c}\text { Average conc. } \\
\text { HPLC [ppm] }\end{array}$ & $\mathbf{s}_{\text {HPLC }}$ & LOQ $_{\text {HPLC }}$ & $\begin{array}{c}\text { Average conc. } \\
\text { GC [ppm] }\end{array}$ & $\mathbf{s}_{\text {GC }}$ & LOQ $_{\text {GC }}$ \\
\hline Amina 8 & 2.9533 & 0.0404 & $\mathbf{0 . 4 0}$ & 3.7920 & 0.1809 & $\mathbf{1 . 8 0}$ \\
\hline Amina 19 & 2.1981 & 0.0316 & $\mathbf{0 . 3 1}$ & 4.0280 & 0.1859 & $\mathbf{1 . 8 5}$ \\
\hline Amina 16 & 2.9898 & 0.0298 & $\mathbf{0 . 2 9}$ & 4.0480 & 0.1571 & $\mathbf{1 . 5 7}$ \\
\hline Amina 21 & 3.0051 & 0.0137 & $\mathbf{0 . 1 3}$ & 3.3360 & 0.2140 & $\mathbf{2 . 1 3}$ \\
\hline Amina 18 & 3.0085 & 0.0143 & $\mathbf{0 . 1 4}$ & 3.4840 & 0.1534 & $\mathbf{1 . 5 3}$ \\
\hline Amina 9 & 2.9956 & 0.0281 & $\mathbf{0 . 2 8}$ & 3.9360 & 0.2459 & $\mathbf{2 . 4 5}$ \\
\hline Amina 7 & 2.9743 & 0.0176 & $\mathbf{0 . 1 7}$ & 3.5020 & 0.1480 & $\mathbf{1 . 4 7}$ \\
\hline Amina 6 & 2.9752 & 0.0178 & $\mathbf{0 . 1 7}$ & 3.8700 & 0.1339 & $\mathbf{1 . 3 3}$ \\
\hline Amina 14 & 2.9676 & 0.0169 & $\mathbf{0 . 1 6}$ & 3.4780 & 0.1770 & $\mathbf{1 . 7 7}$ \\
\hline Amina 17 & 2.9412 & 0.0239 & $\mathbf{0 . 2 3}$ & 4.1000 & 0.0780 & $\mathbf{0 . 7 7}$ \\
\hline Amina 23 & 3.0019 & 0.0188 & $\mathbf{0 . 1 8}$ & 4.4200 & 0.6325 & $\mathbf{6 . 3 2}$ \\
\hline Amina 24 & 2.9923 & 0.0198 & $\mathbf{0 . 1 9}$ & 4.3600 & 0.3145 & $\mathbf{3 . 1 4}$ \\
\hline Amina 3 & 3.0118 & 0.0364 & $\mathbf{0 . 3 6}$ & 3.4000 & 0.1476 & $\mathbf{1 . 4 7}$ \\
\hline Amina 13 & 2.9890 & 0.0191 & $\mathbf{0 . 1 9}$ & 4.3820 & 0.0538 & $\mathbf{0 . 5 3}$ \\
\hline Amina 20 & 3.0447 & 0.0217 & $\mathbf{0 . 2 1}$ & 3.7820 & 0.1541 & $\mathbf{1 . 5 4}$ \\
\hline Amina 15 & 2.9335 & 0.0150 & $\mathbf{0 . 1 4}$ & 4.3480 & 0.0567 & $\mathbf{0 . 5 6}$ \\
\hline Amina 2 & 2.9857 & 0.0212 & $\mathbf{0 . 2 1}$ & 3.9800 & 0.0738 & $\mathbf{0 . 7 3}$ \\
\hline Amina 12 & 2.9313 & 0.0479 & $\mathbf{0 . 4 7}$ & 4.2060 & 0.0550 & $\mathbf{0 . 5 4}$ \\
\hline Amina 1 & 2.9785 & 0.0265 & $\mathbf{0 . 2 6}$ & 4.2440 & 0.1183 & $\mathbf{1 . 1 8}$ \\
\hline Amina 10 & 2.9795 & 0.0202 & $\mathbf{0 . 2 0}$ & 4.2420 & 0.0412 & $\mathbf{0 . 4 1}$ \\
\hline Amina 11 & 2.9900 & 0.0226 & $\mathbf{0 . 2 2}$ & 3.8860 & 0.0898 & $\mathbf{0 . 8 9}$ \\
\hline Amina 5 & 2.9773 & 0.0169 & $\mathbf{0 . 1 6}$ & 3.9180 & 0.0979 & $\mathbf{0 . 9 7}$ \\
\hline Amina 22 & 3.0718 & 0.0213 & $\mathbf{0 . 2 1}$ & 3.9360 & 0.1179 & $\mathbf{1 . 1 7}$ \\
\hline
\end{tabular}


chromatographic methods are shown in table 4 . We determined the values for limits of detection of aromatic amines according to the standard SR EN ISO 14362-1:2017 (table 4); by liquid chromatographic method with spectrophotometric detection HPLCMWD, values are in the range of $0.04-0.14 \mathrm{mg} / \mathrm{L}$ and by the gas chromatographic method with mass selective detector GC-MS are in the range of $0.2-1.9$ $\mathrm{mg} / \mathrm{L}$, which allows a precise detection of amines in the range of 2-50 $\mathrm{mg} / \mathrm{L}$ (specified in standard method). The values of the limits of quantification for aromatic amines by liquid chromatographic method HPLCMWD according to SR EN ISO 14362-1: 2017 are in the range of $0.1-0.5 \mathrm{mg} / \mathrm{L}$, and by gas chromatography method are in the range of 0.4 to $2.5 \mathrm{mg} / \mathrm{L}$, which allows quantification of amines at low levels of concentration (table 5).

\section{CONCLUSION}

In this study, some aspects relating to validation of a precise and reliable method for determining aromatic amines derived from banned azo dyes specific to the textile industry are presented; specific UV absorption wavelength for each compound has been identified and the performance characteristics for both HPLCMWD and GC-MS methods specified in standard SR EN ISO 14362-1:2017 [10] have been determined for an accurate and reliable detection and quantification of multicomponent aromatic amines.

\section{ACKNOWLEDGEMENTS}

The authors acknowledge the financial support of the Romanian Authority for Scientific Research and Innovation (ANCSI) in the frame of the Nucleu Programme, contract PN 16340405.

\section{BIBLIOGRAPHY}

[1] Lavandeira, J.G., Salgado-Pential, C., Blanco, E., Cela, R. A sensitive and efficient procedure for the high throughput determination of banned aromatic amines in textile and leather products aided by advanced sample composition, In: Anal Bioanal Chem. 397:751-763, (2010).

[2] Hunger, K. Industrial Dyes. Chemistry, Properties, Applications, Wiley VCH (2003).

[3] Chequer, F.M.D. et al. Textile Dyes, Dyeing Process and Environmental Impact (2013).

[4] Organisation for economic cooperation and development (2005) Environmental Requirements and Market Access. Chapter 2: Limits on Aromatic Amines in Textiles Coloured with Azo Dyes. In: OECD Publishing. ISBN-92-64-01373-3.

[5] Puntener, A., Page, C. (2004) European Ban on Certain Azo Dyes. Quality and Environment, TFL.

[6] Report by Laboratory of the Government Chemist "The risk of cancer caused by textiles and leather goods coloured with azo dyes", see http://ec.europa.eu/health/.htm

[7] Regulation (EC) No 1907/2006 of the European Parliament and of the Council of 18.12.2006 concerning the Registration, Evaluation, Authorisation and Restriction of Chemicals; OJ L 396, 30.12.2006.

[8] Oeko-Tex® Standard 100, Int. Association for Research and Testing in the field of Textile Ecology, 2015.

[9] Postnote "The Environmental, Health and Economic Impacts of Textile Azo Dyes", Houses of Parliament, Parliamentary Office of Science and Technology.

[10] SR EN ISO 14362:1/2017 Textile: Metoda de determinare a anumitor amine aromatice derivate din coloranti azoici - Partea 1: Detectia utilizarii anumitor coloranti azoici accesibili cu sau fara extractie.

[11] Tanase, I.Gh., Pana, A., Radu, G.L., Buleandra, M. Validarea metodelor analitice - Principii teoretice si studii de caz, Ed. Printech, 2007.

[12] Huber, L. (Ed.) Validation and Qualification in Analytical Laboratories, Interpharm Press, East Englewood, CO, USA, 1998.

Authors:

\section{ELENA PERDUM ${ }^{1}$, ANDREI VALENTIN MEDVEDOVICI ${ }^{2}$, FLORENTIN TACHE ${ }^{2}$, EMILIA VISILEANU ${ }^{1}$, IULIANA DUMITRESCU ${ }^{1}$, CORNELIA-ELENA MITRAN ${ }^{1}$, OVIDIU-GEORGE IORDACHE ${ }^{1}$, ION RAZVAN RADULESCU ${ }^{1}$}

${ }^{1}$ National R\&D Institute for Textiles and Leather Bucharest (INCDTP)

16 Lucretiu Patrascanu, 030508 Bucharest, Romania

e-mail: certex@ns.certex.ro, webpage: http://www.certex.ro

2 University of Bucharest, Faculty of Chemistry, Department of Analytical Chemistry, 90-92 Panduri Street, 050663 Bucharest, Romania webpage: http://www.chimie.unibuc.ro/

\section{Corresponding author:}

